\title{
Esse Canto imantado: Ascese e eXCESSO Na líRICA DE Hilda HiLST
}

\section{Cleide Maria de OliVEIRA*}

\section{Resumo}

$\mathrm{O}$ artigo busca identificar na lírica de Hilda Hilst posterior à década de $70 \mathrm{um}$ movimento de verticalização do objeto do canto amoroso, que ora está no campo da imanência, ora é divinizado por meio de interpolações de caráter negativo como Cara Escura, Aquele Outro, Nada, Sem Nome, Obscuro, Grande Face etc. Defende que haja um cantar de amor como método de transcendência, tanto do sujeito lírico, que sofre a coita amorosa, como do amado que provoca esse sofrer. Esse canto se organiza a partir de dois movimentos pendulares que sustentam a lírica hilstiana: a ascese, enquanto movimento de desprendimento de si, e o excesso, como investimento absoluto na paixão amorosa e método privilegiado de conhecimento de Deus.

Palavras-chave: Hilda Hilst; lírica; ascese; excesso; representações de Deus.

"Ruiska, o que é que procuras? Deus? E tu pensas que ele se fará aqui, na tua página? No teu caminhar de louco? No silêncio de tua vaidade? Sim, no teu caminhar de louco, em ti todo fragmentado, abjeto. Ele se fará na vontade que tens de quebrar o equilibrio, de te estilhaçares [...]"

(HILST, 2018, p. 52)

Na poesia de Hilda Hilst, a ideação de Deus - que não é outro senão o Deus da tradição judaico-cristã - constitui um exercício especulativo extremamente honesto, e portanto excruciante, que podemos acompanhar em títulos de poesia como "Exercícios para uma ideia" (1967), "Poemas

Professora de Língua e Literatura no Centro Federal de Educação Tecnológica de Minas Gerais/ CEFET-MG, Belo Horizonte, Minas Gerais, Brasil. E-mail cleideoliva@cefetmg.br. Orcid iD: XXXX. 
malditos, gozosos e devotos” (1984), "Sob a tua Grande Face” (1986), "Amavisse” (1989), "Via Espessa” (1989), "Do desejo” (1992); e de prosa Kadosh (1973), A Obscena Senhora D (1982), Com meus olhos de cão $(1986)^{1}$. Há nesses títulos de poesia um modo particular de articulação entre a voz lírica e a Alteridade a quem a mesma se dirige, qual seja, o paradigma da coita amorosa, própria das cantigas de amor galegoportuguesas de matriz medieval, que na autora se presentifica tanto nos poemas amorosos quanto nos poemas de viés místico. Hilda Hilst se dedicou a um diálogo com essa tradição poética e cultural que foi o amor cortês - fortemente presente nos livros Trovas de muito amor para um amado senhor (1960), Cantares de perda e predileção (1983) e Cantares do sem nome e de partidas $(1995)^{2}$. Desse modo, cabe perguntar de que forma e com quais produções de sentido essa tradição se faz presente quando está a se falar do amor místico, ou seja, do amor dedicado a um Ser ou Presença metafísica, no mais das vezes revestido de características cristãs. A lírica hilstiana opera à semelhança dos escritos de algumas beguinas $^{3}$, como Matilde de Magdeburgo, Margarete Porete e Hadewijch de Amberes, mulheres extraordinárias que fundiram as convenções da cortesia amorosa com o ímpeto místico e forjaram uma obra singular em que o amor erótico é matriz para a poesia religiosa.

1 A partir de agora estes livros serão designados como: SATGF (1986), A (1989), VE (1989), DD (1992), K (1973), AOSD (1982), CMOC (1986).

2 A partir de agora estes livros serão designados como TDMAPAS (1960), CPP (1983), CDSNEP (1995).

3 O movimento conhecido como beguino é o equivalente feminino aos begardos, que nasceu em torno de 1210 nos arredores de Liége, e rapidamente chegou à Colônia, identificando-se com a Alemanha. Apesar das relações estreitas com os franciscanos, as beguinas não eram reconhecidas por eles na Ordem, na verdade o movimento continua autônomo, sem se ligar a nenhum movimento masculino. Entre suas principais características estão a devoção, o celibato e as boas obras. Além dessas, outras de suas características eram: ele não tinha nenhum santo fundador; não buscava nenhuma autorização da Santa Sé; não tinha nem organização nem constituição; não prometia nenhum benefício e não buscava patronos; seus votos eram uma declaração de intenção, e não um comprometimento irreversível a uma disciplina imposta pela autoridade; e seus membros poderiam continuar suas atividades normais no mundo. 
Diversos críticos ${ }^{4}$ da obra de Hilda Hilst notam certa transformação em sua lírica que, apesar de manter a dicção elevada dos primeiros livros, perde o viés idealizante a partir da década de 70 - momento em que a poeta faz sua incursão na prosa após ter se dedicado ao gênero teatro e se materializa em um cantar da ausência amorosa, sendo esta tanto humana quanto divina. Particularmente interessante é a continuidade temática em sua poesia quando abandona a idealização amorosa dos primeiros livros e a busca pelo sublime se verticaliza em um exercício contínuo de interpolação a um Deus inominado e inominável cuja presença negativa é sentida com pesar e paixão. A continuidade de que estamos falando é a do ethos da alteridade (ora divina, ora humana) a quem se dirige esse canto imantado ${ }^{5}$ com uma retórica ao mesmo tempo apaixonada e violenta, e essa alteridade se comporta de forma semelhante, quer seja humana, quer seja divina: com sobranceria, frieza, distanciamento.

A ambiguidade Desse a quem esse cantar se dirige fica explícita mesmo na lírica amorosa dos livros mais claramente em diálogo com as cantigas medievais (CDPEP, 1983 e CDSNEDP, 1995), na qual se repete o procedimento das nomeações imprevistas à uma alteridade,

$4 \quad$ Alguns desses críticos são: Ribeiro (1981); Duarte (2009); Coelho (1999); Moraes (1999). As diferenças entre a poesia anterior e o exercício do teatro e da prosa (anterior à 1974, quando publica Júbilo, memória, noviciado da paixão, livro geralmente apontado como marco de um amadurecimento estilístico) são a "contaminação" dos gêneros prosa, poesia e teatro no que se refere a recursos estilísticos próprios a cada um; o maior grau de organicidade temática que sua lírica mostra; a potencialização do erotismo já pré-existente nos poemas amorosos anteriores a esta data, incluindo aí sua incursão pela "pornografia" (a conhecida tetratologia: O caderno rosa de Lory Lamb, Contos d'escárnio - textos grotescos, Cartas de um sedutor e o conjunto de poemas Bufólicas); o aprofundamento da temática religiosa, já presente esporadicamente nos textos poéticos, mas que ganha novo impulso místico; uma "busca intensa de comunicação" que faz com que ideias como Deus, Morte, Vida, Desejo, Amor se personifiquem em possíveis interlocutores da poeta (DUARTE, 2009, p. 137); a categoria de Tempo como "amarra conceitual" para os principais eixos temáticos da autora (Amor, Morte, Deus) (DUARTE, 20090, p. 139).

5 "Que se a mim não deram/Esplêndida beleza/Deram-me a garganta/Esplandecida: a palavra de ouro/A canção imantada/O sumarento gozo de cantar/Iluminada, ungida”, trecho do poema IX do segmento "Ode descontínua e remota para flauta e oboé. De Ariana para Dionísio", série de poemas parte do livro Júbilo, Memória, Noviciado da Paixão (1974). 
procedimento que se assemelha àquelas outras nomeações, claramente divinas. Dizendo de outra forma, há um embotamento das fronteiras entre imanência e transcendência quando se trata do objeto a quem se direciona o canto lírico, muito embora alguns livros e/ou poemas não deixem dúvida de que se dirigem a uma alteridade não humana, nomeada como Deus ou com nomes tão contraditórios e ambíguos como o Cara Escura, O Grande Obscuro, Aquele Outro, o Sem Nome, o Máscara de Nojo, o Guardião do Mundo, o Tríplice Acrobata... Noutros o destinatário desse cantar é um outro, muito amado, mas não divinizado.

Proponho uma leitura que visibilize a transformação ("evolução"?) de um cantar de amigo em que a coita amorosa situa o Amado nas alturas do desejo, divinizando-o até a um ponto onde o ser que se deseja e se lamenta seja apenas AUSÊNCIA e DESEJO. Ou seja, a transformação progressiva de um amado humano indiferente e displicente em um Deus não menos reticente em seus afetos. Nesse sentido, talvez possamos falar do cantar de amor como um método de verticalização para as interpolações ao divino que se farão presentes na lírica (e também na prosa, como nas narrativas citadas anteriormente), veja-se, por exemplo, o poema VII, do livro CPP (1983), no qual se delineia uma metodologia ascética que tem nos afetos sua centralidade:

E se leopardos e tigres convivessem

E se o mundo houvesse

Lonjura de cordas

Para amarrar torres vastas

(as incansáveis crias do desejo)

E se águas não fossem molhadas

E o que fosse montanha

Ao invés de altura

Se fizesse rasa

Se o fogo não tragasse

Sua própria espessura 

E a lucidez perfeita
Não fosse embriaguez
Do teu excesso
E da minha loucura
Um caminho adequado
Em direção a Deus.

As quatro estrofes iniciais do poema contêm uma pergunta marcada por uma conjunção condicional, sendo que nas três primeiras se têm ainda uma conjunção aditiva ("e"), que confere ao poema ares de diálogo continuado, com interlocutor oculto. A questão proposta é a de situações hipotéticas, não factíveis ou não verossímeis, que parecem constituir a base para a construção de um "caminho adequado" a Deus (vs 18-19). E que condições são estas: a convivência pacífica de tigres e leopardos, a lonjura de cordas para amarrar as torres do desejo, águas que não se molhem, montanhas rasas, fogo que não se consuma a si mesmo, divórcio entre lucidez e embriaguez. Tais condições, por serem absurdas, apontam tanto para a dificuldade dessa empreitada quanto para um espaço utópico onde o excesso de um e a loucura de outro constroem um método sui generis que nos faz recordar a teoria platônica sobre o amor, posta na boca de Diotima, em $\mathrm{O}$ banquete, de Platão:

Quando então alguém, subindo a partir do que aqui é belo, através do correto amor aos jovens, começa a contemplar aquele belo, quase que estaria a atingir o ponto final. Eis, com efeito em que consiste o proceder corretamente nos caminhos do amor ou por outro se deixar conduzir: em começar do que aqui é belo e, em vista daquele belo, subir sempre, como que servindo-se de degraus, de um só para dois e de dois para todos os belos corpos, e dos belos corpos para os belos ofícios, e dos ofícios para as belas ciências até que das ciências acabe naquela ciência, que de nada mais é senão daquele próprio belo, e conheça enfim o que em si é belo. Nesse ponto da vida, meu caro Sócrates, continuou a estrangeira de Mantinéia, se é que em outro mais. poderia o homem viver, a contemplar o próprio belo. (PLATÃO, 1991, p. 86-87) 
Tal metodologia fica clara nas palavras de Diotima à Sócrates: o amor é uma ascese que nos conduz ao Belo em si mesmo, o qual, segundo ainda a concepção platônica, é idêntico ao Bom e ao Verdadeiro. Beleza, Bondade e Verdade são outros nomes do divino, dessa alteridade absoluta que, talvez, desde sempre, tem fascinado e aterrorizado a humanidade ${ }^{6}$.

No mesmo livro (CPP), ainda em 1983, põe-se em prática um procedimento que será largamente utilizado em sua posterior: o uso de apóstrofes formadas por adjetivos e/ou substantivos comuns com iniciais maiúsculas, procedimento que passará a ter, a partir de PMGED (1984), a clara intenção de um chamamento ao divino, mas que nesse livro ainda é de destino ambíguo, veja-se exemplo:

Há este Nunca-Mais

Ancorado no Tempo.

E uma só tarde num aroma de ruas

De mogorim, de aves (Poema LVII)

E também ambíguo é tal procedimento no livro anterior, JMNP, de 1974:

Livra-me de ti. Que eu reconstrua

Meus pequenos amores. A ciência

De me deixar amar

Sem amargura. E que me deem

A enorme incoerência

De desamar, amando. E te lembrando

- Fazedor de desgosto -

Que eu te esqueça. (Poema X)

6 Em seu clássico estudo sobre os aspectos racionais e irracionais do fenômeno religioso, Otto (2005, p. 38) o define como um totalmente outro que nos causa admiração, fascínio, mas também temor: "assombro "Mas o mistério religioso, o autêntico mirum é - para dizer talvez da maneira mais justa - o heterogêneo, o thateron, amyad, alienum, o estranho e chocante, aquilo que resolutamente sai do círculo do habitual, entendido, familiar, íntimo, opondo-se a eles e, portanto, enche o ânimo com intenso espanto". 
Entretanto, em CDSNEP, de 1995, último livro publicado por Hilda Hilst, a ambiguidade recua até quase se extinguir, e o exercício de definição do Amor, visto nos livros anteriores, culmina nas nomeações absolutizantes em muito semelhantes àquelas que foram usadas nos poemas mais decididamente místicos de PMGED e SATGF, vejam-se exemplos em um conjunto de poemas que se dedicam a caracterizar um "Isso de mim que anseia despedida", mas "não tem nome de amor" a partir do já conhecido processo de negação:

Não tem nome de amor. Nem se parece a mim.

Como pode ser isso? Ser tenro, marulhoso

Dançarino e novo, ter nome de ninguém

E preferir ausência e desconforto

Para guardar no eterno o coração do outro.

(Poema III)

No poema seguinte (IV), as perguntas retóricas continuam a ser propostas:

E por quê, também não doloso e penitente?

Dolo pode ser punhal. E astúcia, logro.

E isso sem nome, o despedir-se sempre

Tem muito de sedução, armadilhas, minúcias

Isso sem nome fere e faz feridas.

Penitente e algoz:

Como se só na morte abraçasse a vida.

Por fim, uma tentativa mais explícita de nomeação: "Fêmea-rapaz, isso sem nome pode ser um todo/Que só se ajusta ao Nunca. Ao Nunca Mais” (poema IV), mas a nomeação parece falha ou ilusória na medida em que

O Nunca Mais é só meia-verdade.

Como se visses a ave entre a folhagem

E ao mesmo tempo não. 
Será esse o mesmo Nunca Mais que aparece em CPP, de 1983? Aquele cuja interpretação como uma espécie de conjuração espaçotempo onde os amantes se localizam e o embate entre ódio-amor acontece parece plausível (como aparece no trecho do poema LVII, anteriormente comentado)? Mas aqui, 12 anos depois, o Nunca Mais se reveste de mistério e astúcia (poema IV), tendo muito de "sedução, armadilha, minúcias” (poema VI, v. 3), características sobejadamente atribuídas à persona divina nos poemas místicos. A questão, ainda que aparentemente sem maior relevância hermenêutica, é de difícil resposta. Nesses dois livros de poemas que formarão depois o volume único de Cantares (2001), têm-se os poemas claramente místicos-eróticos de PMGED (1984), SATGF (1986), A (1989), VE (1989), VV (1989) DD (1992). A hipótese que delineia nosso percurso interpretativo neste estudo é a de que mesmo quando o sujeito amoroso a quem se dirige esse cantar não seja esboçado como um Outro absoluto, há latente nessa idealização amorosa um quê de sublime que faz com que o deslizamento para os poemas místicos eróticos seja tão "previsível” que não sabemos responder por cada uma das apóstrofes, que ora são divinas, ora são humanas. Um panorama brevíssimo dos poemas místico-eróticos nos livros citados, que foram publicados no intervalo entre CPP (1983) e CDSNEDP (1995), estes dois livros onde o diálogo com a tradição das cantigas de amor e de amigo galego-portuguesas se intensifica, pode demonstrar que o pensar a Deus a partir da ótica erótico-amorosa é um exercício no qual o objeto do canto lírico se transcendentaliza sem se "espiritualizar", ou seja, há o aproveitamento de procedimentos estético-filosóficos usados nos poemas amorosos, bem como a "elevação" do Amado do qual se canta o distanciamento e a indiferença e que se transforma em um deus com evidentes traços gnósticos.

Poesia amorosa e poesia mística se amalgamam após a publicação de CPP e, por outro lado, nos livros subsequentes temos procedimentos discursivos que remetem à essa obra, quais sejam: a eleição da retórica amorosa como discurso próprio para a interpolação à figura divina e o privilégio temático do sofrimento amoroso (ou coita). Um poema 
interessante para se começar tal painel é o primeiro (sem numeração, que após ele inicia-se normalmente) de A (1989):

Porco-poeta que me sei, na cegueira, no charco

Á espera da Tua Fome, permita-me a pergunta

Senhor de porcos e de homens:

Ouviste acaso, ou te foi familiar

Um verbo que nos baixios daqui muito se ouve

$\mathrm{O}$ verbo amar?

Porque na cegueira, no charco

Na trama dos vocábulos

$\mathrm{Na}$ decantada lâmina enterrada

Na minha axila de pelos e de carne

$\mathrm{Na}$ esteira de palha que envolve a alma

Do verbo apenas entrevi o contorno breve:

É coisa de morrer e de matar mas tem som de sorriso.

Sangra, estilhaça, devora, e por isso

De entender-lhe o cerne não me foi dada a hora.

É verbo?

Ou sobrenome de um deus prenhe de humor

na péripla aventura da conquista?

Nesse monólogo que é o poema temos uma voz lírica que se intitula "Porco-poeta" e que se dirige àquele que chama de "Senhor de porcos e de homens" para perguntar-lhe se conhece uma palavra, não por acaso um verbo (que nos remete a uma ação), o verbo "amar". O epíteto, tido como algo escandaloso para Deus, deve ser interpretado à luz da predileção confessa de Hilst pelos porcos: "Vocês viram, eu tenho ali um retrato de uma moça beijando um porco; eu adoro porcos" (HILST, 1999). Ou seja, não há blasfêmia apesar do inusitado da adjetivação. Estão postos, simetricamente, o "Senhor dos porcos" e o "Porco-poeta", criador e criatura, como os sujeitos desse discurso que 
se erige como pergunta retórica a um interlocutor invisível e que tem seu "fecho de ouro", como nos sonetos clássicos, na irônica afirmação dos versos 17-18: não seria o verbo amar o outro nome de um Deus espécie de Dom Juan - empenhado na conquista erótico-amorosa ${ }^{7}$ ? O amor, ou Deus, segundo essa lógica interna ao poema, "sangra, estilhaça e devora", ultrapassando toda possibilidade de entendimento (vs. 1415), provocando a coita amorosa tão presente nos poemas hilstianos, com a diferença de que aqui as ações "sedutoras" desse Amante divino são motivadas por um humor particular - vs. 17 - talvez a nós incompreensível.

Uma outra menção ao idiossincrático humor divino está no poema III de PMGED (1984), passemos a ele:

Caio sobre teu colo

Me retalhas.

Quem sou?

Tralhas, do teu divino humor.

Coronhadas exatas

De tuas mãos sagradas.

Me queres abatida, gasta

E antegozas o gosto

de um trêmulo Nada,

Me devoras

Com teus dentes ocos.

A ti me incorporo

A contragosto

Sou agora fúria

E descontrole.

Agito-me desordenada

Nos teus moles.

7 Lembremo-nos que em livro anterior (PMGD, poema II) Ele foi chamado de "um sedutor nato". 
Sou façanha

Escuro pulsante

Fera doente.

À tua semelhança

Homem.

"Coronhadas exatas" são o que nos oferecem as mãos sagradas, violência com objetivo claro, e óbvio: ter "esbatida, gasta" o sujeito amoroso a ser devorado e incorporado à pessoa divina, que aguarda com impaciência provar o "gosto/de um trêmulo Nada" (vs. 8-9). Após esse devoramento erótico, o sujeito desse cantar, que mais parece de ódio e não de amor, se define ("Sou agora", v. 14) nos substantivos "fúria", "descontrole", "façanha", "escuro pulsante", e com o adjetivo "desordenada", para terminar na síntese dos dois últimos versos: "À tua semelhança/ Homem”. Essa delimitação apela a termos pouco comuns para se pensar um Deus, pois não nos esqueçamos, é essa identidade que o penúltimo verso explicita, logo, temos um Deus muito distante dos ideais platônicos e/ou cristãos de equilíbrio, amor e sabedoria. Esse ser divino é amante oblíquo e ambíguo, como aparece nessa imagem perturbadora do poema abaixo, onde Ele é identificado com a figura de um menino, uma criança que chora, enquanto inflige dor:

\section{Tem tríplices caninos. \\ Te trespassa o rosto \\ E chora menino \\ Enquanto agonizas.}

Se esta relação entre eu lírico e Deus é tensa, este, ainda que apaixonado, não assume postura passiva, como fica evidente no poema abaixo (V, DD, 1992):

Existe a noite, e existe o breu.

Noite é o velado coração de Deus

Esse que por pudor não mais procuro. 
Breu é quando tu te afastas ou dizes

Que viajas, e um sol de gelo

Petrifica-me a cara e desobriga-me

De fidelidade e de conjura. O desejo,

Este da carne, a mim não me faz medo.

Assim como me veio, também não me avassala.

Sabes por quê? Lutei com Aquele

e dele também não fui lacaia.

Noite e breu são duas instâncias que sintetizam os relacionamentos do sujeito lírico com Deus e com esse Tu sem mais caracterização, o que aliás parece ser uma característica da lírica amorosa de Hilda Hilst, não oferecer descrições precisas do objeto amado, o que contraria um traço típico da poesia amorosa, veja-se exemplo em Petrarca, aquele que nos legou um modelo do cantar de amor, que louva a beleza de sua musa Laura:

Eram os cabelos d'ourados esparsos ao vento

que em mil doces nós a envolvia,

e a vaga luz resplandecia desmedida

daqueles bonitos olhos, que hoje não existem;

e o rosto transformando-se em piedosas cores

não sei se me parecia real ou uma ilusão:

eu que tinha a isca amorosa no peito

por qual maravilha logo fui tomado ${ }^{8}$

Entretanto, na lírica hilstiana o Amado não é louvado, quer por sua excelência física, quer por seus dotes intelectuais, morais ou artísticos. Ao contrário, o que se sabe, por meio de uma constante queixa do sujeito amoroso, é da indiferença e/ou crueza do amado, mesmo quando se trata dos poemas místicos.

A noite corresponde ao coração de Deus, caracterizado como “velado", e talvez por isto já não mais buscado, por "pudor”. O breu se

8 Tradução de SOUZA, 1996. 
encontra no campo da imanência, e nos fala do binômio Ausência-Desejo. Não obstante, se, ou quando, esse Tu se afasta não há medo no eu lírico, e o próprio desejo "Não me (a) avassala" (v. 09). A resposta, oferecida coloquialmente ao interlocutor ausente, que parece ser o Tu a quem se dirige os afetos passionais do sujeito amoroso, é a confissão de uma vez ter lutado com "Aquele" - e a maiúscula não deixa dúvidas de que se trata do Deus do $2^{\circ}$ verso - e não ter se submetido. Tal suposto episódio - um combate com o divino - recupera a narrativa bíblica de Gênesis 32, 2232 , quando Jacó, o mais ladino de todos os patriarcas, se encontra com um ser apenas caracterizado com "alguém” pelo texto bíblico, com quem trava uma intensa batalha durante toda uma noite. Ao amanhecer, esse ser indefinido "toca” na coxa de Jacó, deixando-o manco, mas ainda assim Jacó não interrompe a luta, e diante disto o ser pede-lhe que o deixe ir, ao que Jacó responde que apenas pararia o combate se esse o abençoasse. Além da benção - que era tão real e concreta para os antigos hebreus como uma montanha ou uma cadeira - Jacó ganha um novo nome de significado assombroso: "Seu nome não será mais Jacó e sim Israel, porque você lutou com Deus e com os homens e venceu” (BÍBLIA SAGRADA, Gênesis 32, 28). O novo nome de Jacó deixa a entender que a identidade do misterioso personagem era divina - mais provavelmente uma hierofania sua - e tal hipótese se confirma com a continuação do texto bíblico (v. 31), em que diz que José chamou aquele lugar de Fanuel, que significa "Face de Deus".

\section{$\& \& \&$}

Mas, se Esse tão desejado não sabe ou não quer conjugar o verbo amar no tempo dos homens, inventa-se a erótica vicária - a que chamou atenção Alcir Pécora - da qual o poema baixo (DD, 1992) é exemplar:

Porque há desejo em mim, é tudo cintilância.

Antes, o cotidiano era um pensar alturas

Buscando Aquele Outro decantado.

Surdo à minha humana ladradura.

Visgo e suor, pois nunca se faziam.

Hoje, de carne e osso, laborioso, lascivo

Tomas-me o corpo. E que descanso me dás 
Depois das lidas. Sonhei penhascos

Quando havia o jardim ali do lado.

Pensei subidas onde não havia rastros.

Extasiada, fodo contigo

Ao invés de ganir diante do Nada.

Vicário se diz quando alguma coisa, ou alguém, toma o lugar de outra, do latim vicarius, "fazer as vezes de", "substituir outra coisa ou pessoa”. No poema lido e em outros, a substituição é clara: há um "tu”, evidente em versos como "Tomas-me o corpo. E que descanso me dás" (v. 6), e um misterioso "Aquele Outro" que também equivale ao "Nada" do $11^{\circ}$ verso. Sendo este indiferente ("surdo") ao desejo que alimenta o sujeito lírico, "visgo e suor" não se realizam (v. 5), exceto quando se materializam na persona desse $\mathrm{Tu}$, interlocutor invisível que é de humana carnadura, como fica explícito no verbo "foder" a ele relacionado.

E, no mesmo livro (poema VI), a substituição vicária de um Outro incorpóreo prossegue, ainda que seus resultados não sejam mais do que provisórios:

Aquele Outro não via minha muita amplidão.

Nada Lhe bastava. Nem ígneas cantigas.

E agora vã, te pareço soberba, magnífica

$\mathrm{E}$ fodes como quem morre a última conquista

$\mathrm{E}$ ardes como desejei arder de santidade.

(E há luz na tua carne e tu palpitas).

Ah, por que me vejo vasta inflexível

Desejando um desejo vizinhante

De uma Fome irada e obsessiva?

Troca-se a santidade pela carne que se ilumina e palpita no gozo da conquista, entretanto o Desejo não se basta, pois há uma "Fome irada e obsessiva” (v. 9) que perdura e assombra o sujeito desse canto. Em poema posterior (IX) este confessa a interlocutor enciumado - que reclama querer também "a alma/na tua (sua) cama” (vv. 1-2) - não ter omitido "que a alma está além, buscando/ Aquele Outro" (vv. 6-7). E, logo após, no 
poema seguinte $(\mathrm{X})$, a efetividade desta erótica vicária é posta em questão com a afirmação de que gozo maior está em "pensar o Outro" (v. 13), pois há uma especificidade muito peculiar a esse desejo que é o transcender o corpo; ainda que nele se localize, é "Incorpóreo" e só se realiza no delírio ou no verso, que são fonte de gozo na medida em que o próprio exercício de pensar a Deus tem potência erótica. Vejam-se os versos finais do poema citado:

Para pensar o Outro, eu deliro ou versejo.

Pensá-lo é gozo. Então não sabes? INCORPÓREO É O DESEJO.

Conjugado de forma complementar ao poema acima, leiamos o de número VII, do livro DN (1992):
Dunas e cabras. E minha alma voltada
Para o fosco profundo da Tua Cara.
Passeio meu caminho de pedra, leite e pelo.
Sou isto: um alguém-nada que te busca.
Um casco. Um cheiro. Esvazia-me de perguntas.
De roteiros. Que eu apenas suba. (poema VII, Da Noite, 1992)

Nesses poemas, temos dois princípios estruturantes desse método amoroso de transcendência: a ascese e o excesso 9 . O delírio e o verso são a contraparte desse processo de desnudamento que transforma o sujeito amante em um "alguém-nada" (v. 4), vazio de perguntas e de roteiros (vv. 5-6). Em outro poema (I, SATGF) este mesmo amante especula:

Talvez assim te encantes de tão farta nudez.

Talvez assim me ames: desnudo até o osso.

Igual a um morto.

9 A própria biografia de Hilda Hilst é uma curiosa mescla de ascese e excesso. Heringer (2017, p. 533) sobre a questão assim se pronuncia: "Suas entrevistas revelam como a própria autora se dedicou a construir sua imagem pública e a reivindicar espaço no meio literário. Essa autoconstrução, que dançou ao saber dos capricci da imprensa, apesar da constante tensão com eles, desaguou na imagem que hoje se tem de Hilda Hilst: a reclusa da Casa do Sol, com dezena de cães. Hilda, que apareceu no Fantástico nos anos 1970 dizendo que gravava as vozes dos mortos. Hilda provocadora, desbocada, obscena, meio louca, eremita, arredia, indomesticável. Os adjetivos são muitos, e quase todos indicam certo descontrole." 
Mas nem só de ascese sustenta-se a poesia místico-erótica de Hilda Hilst, veja-se o poema abaixo retirado do interessante livro Via Espessa (1989), que contém apenas 17 poemas, dos quais 15 apresentam a figura de um louco, que ora é um duplo, ora é uma sombra do poeta, quase sempre um interlocutor impertinente que faz perguntas retóricas, mas não menos difíceis de responder. Nos outros poemas, a loucura está presente também, como "campo de estalagem" onde o poeta habita (poema I), ou na figura de Dionísio, o deus do excesso e das bacantes, a quem a poeta segue "a carne, a ebriedade" (poema II).

De canoas verdes de amargas oliveiras

De rios pastosos de cascalho e poeira

De tudo isso meu cantochão tecido de ervas negras.

Grita-me o louco:

De amoras. De tintas rubras do instante

É que se tinge a vida. De embriaguez Samsara.

E atravessou no riso a tarde fulva. (Poema XI)

Nominado de Samsara ${ }^{10}$ - aquele que anda em círculos - pelo louco, a poeta descreve-nos um cantochão, que vem a ser uma prática monofônica de canto usado em liturgias cristãs, em suas origens desacompanhado. É também a forma de música ocidental mais antiga e ainda usada em mosteiros e em coros leigos das igrejas cristãs. Ou seja, é um canto ritual, religioso, solene, antigo. Canto que o louco equipara à vida (vv. 5-6). Esse canto idealizado pelo poeta, terá em sua substância canoas verdes feitas com madeiras de amargas oliveiras, rios feitos de cascalho e poeira, e será tecido de ervas negras. Percebe-se que algumas cores tingem esse canto: o verde das canoas, o cinza e o marrom do cascalho e da poeira, o negro das ervas. A essas cores o louco contrapõe o vermelho vivo das amoras, das "tintas rubras do instante", e do sangue que corre em nossas veias, para sugerir à Samsara que as nobres e sisudas cores que estava a usar não são adequadas para a tintura da vida, pois essa se conjura no excesso e na embriaguez (v. 6). Em outro poema do mesmo livro o louco pergunta: “

10 “Termo sânscrito (literalmente "corrente, migração") que no hinduísmo e no budismo indica o fluir incessante das coisas e o ciclo das reencarnações” (ABBAGNANO, 2012, p. 1024). 
Não percebes, Samsara ...... Que o cinza é a cor do teu queixume/ e o grito tem a cor do sangue Daquele que se esconde?/ Vive o carmim Samsara. A ferida" (poema XVI).

E ainda, o louco a Samsara: "-Esquece texto e sabença. As cadeias do gozo./E labaredas do intenso te farão voo." (poema XIII).

\section{$\& \& \&$}

Retomemos o que foi anteriormente dito sobre a cantiga eróticoamorosa ser, em Hilda Hilst, parte de um método de ascensão do e ao divino, divino que ora aparece sob o nome de Deus, em maiúscula, ora, na maior parte das vezes, em apóstrofes de valor apofático, como por exemplo Aquele Outro, Aquele, Cara Escura, O Grande Obscuro, Sem Nome, Grande Face etc. Esse "método", como dito anteriormente, teria como elementos estruturantes a ascese e o excesso.

Cabe explicar um pouco mais o que se quer dizer.

Apesar de podermos encontrar vestígios vigorosos desses dois movimentos na biografia de Hilda Hilst, não é exatamente neste âmbito que quero me deter. Ainda que a vida de Hilda tenha sido realmente impressionante, não é ela que me interessa aqui, e sim sua obra, a qual tem sido obscurecida muitas vezes pelo brilho dessa mulher singular, como mencionado diversas vezes por Álcir Pécora, organizador da obra da autora publicada pela editora Globo. Ascese e excesso são instâncias pendulares que organizam a poesia lírica hilstiana, e estou falando aqui de princípios estéticos, teológicos e filosóficos, em um exercício teopoético, no sentido em que o mesmo Pécora afirmou serem os textos de Hilda "exercícios de estilo" 11

11 Segundo Pécora (2005, on-line): "Em primeiro lugar, cabe considerar que os textos de Hilda se efetuam, em larga medida, como exercícios de estilo, isto é, eles fazem o que lhes é próprio com base no emprego de matrizes canônicas dos diferentes gêneros da tradição, como, por exemplo, os cantares bíblicos, a cantiga galaico-portuguesa, a canção petrarquista, a poesia mística espanhola, o idílio árcade, a novela epistolar libertina etc. Em segundo lugar, é fácil perceber que essa imitação à antiga jamais se pratica com purismo arqueológico, mas, bem ao contrário, submetida à mediação de autores decisivos do século XX: a imagética sublime de Rilke; o fluxo de consciência de Joyce, a cena minimalista de Beckett, o sensacionismo de Pessoa, apenas para referir a quadra de escritores internacionais mais fácil de reconhecer em seus escritos". 
O substantivo ascese, de origem grega, que em sua origem significa "exercício", e primitivamente as regras de conduta e treinamento dos atletas, possui íntima relação com termos relativo a esforço, disciplina e trabalho para o desenvolvimento de uma habilidade, como os termos meléte e gymnastiké. Posteriormente, com os pitagóricos, os cínicos e os estoicos, seu sentido se estendeu à vida moral, na medida em que se compreendia que o exercício da virtude implicava uma boa dose de renúncia e autoimposição de limites (ABAGGANO, 2007, p. 83). De acordo com Pinheiro (2020), o conceito de ascese apresenta dois polos de compreensão:

[...] ambos baseados em uma ideia de treinamento humano em relação aos seus desejos com vistas a um aprimoramento moral e espiritual. No primeiro, uma renúncia, repressão e mortificação das tendências e impulsos corpóreos; no segundo, um refinamento e um redirecionamento do desejo inicialmente vinculado ao mundo humano e mortal, para que ele se volte em direção ao espiritual e eterno, em direção à vita contemplativa, seja contemplando as ideias (pagã-neoplatônica) seja na unio mística (cristã), com a experiência da presença de Deus (p. 1)

Em sua acepção filosófica, Foucault (2010) caracteriza a prática de ascese não como uma renúncia de si, mas, pelo contrário, como uma constituição de si mesmo cujo objetivo é a formação “ [...] de uma certa relação de si para consigo que fosse plena, acabada, completa, autossuficiente e suscetível de produzir a transfiguração de si que consiste na felicidade que se tem consigo mesmo" (FOUCAULT, 2010, p. 285).

Por outro lado, o substantivo "excesso" tem como sinônimos abundância, demasia, exorbitância, fartura, redundância, superabundância, descomedimento, imoderação, intemperança, entre outros. A noção de excesso pode ser aproximada teoricamente do conceito de soberania, de Georges Bataille, um pensador que se propôs a entender o que nos excede enquanto seres da razão. A soberania relaciona-se à gratuidade e ao excesso, no sentido em que implica uma autoridade e um poder que não se limita 
por outro. Bataille (1992) identificará a história com as necessidades do mundo do interdito e do trabalho, e nesse sentido a soberania - entrevista nos movimentos eróticos - é um movimento afirmativo para "fora” dos limites da racionalidade que fundamenta a experiência humana. Ele compara os estados de êxtase proporcionados pela experiência mística com os jogos erótico-amorosos, apontando neles um mesmo estado de soberania em que o homem experimenta um desapego a conservação da vida, e uma indiferença a tudo que tende a assegurá-la (a existência) e, ao mesmo tempo, uma extraordinária alegria que advém desse abandono de si. A análise de Bataille (1992) sobre o erotismo (dos corpos, corações e sagrado) enfatiza que ele é, antes de tudo, uma operação soberana, na qual o interdito foi rompido pela violência da transgressão. $\mathrm{O}$ erotismo revela do humano uma faceta obscura: o excesso, a soberania, a parte maldita.

Após esse mínimo esclarecimento conceitual, pergunta-se: onde ver-se-ia ascese e excesso na poesia hilstiana? Para responder a esta questão, retomemos o poema I do livro SATGF (1986), do qual comentamos os últimos versos:

Honra-me com teus nadas.

Traduz meu passo

De maneira que eu nunca me perceba.

Confunde estas linhas que te escrevo

Como se um brejeiro escoliasta

Resolvesse

Brincar a morte de seu próprio texto.

Dá-me pobreza e fealdade e medo.

E desterro de todas as respostas

Que dariam luz

A meu eterno entendimento cego.

Dá-me tristes joelhos.

Para que eu possa fincá-los num mínimo de terra

$\mathrm{E}$ ali permanecer o teu mais esquecido prisioneiro.

Dá-me mudez. E andar desordenado. Nenhum cão.

Tu sabes que eu amo os animais

Por isso me sentiria aliviado. E de ti, Sem Nome 
Não desejo alívio. Apenas estreitez e fardo.

Talvez assim te encantes de tão farta nudez.

Talvez assim me ames: desnudo até o osso

Igual a um morto.

Até o verso 17, o poema tem uma estrutura semelhante em que esse ser denominado Sem Nome desenvolve ações relacionadas ao sujeito lírico e amoroso, ações as quais poderíamos denominar ascéticas, pois resultam em estados negativos, como por exemplo o "desterro de todas as respostas” (v. 9). Dos versos 17 a 21 temos uma reflexão do sujeito lírico sobre a influência dessas práticas ascéticas sobre o ser divino, especulando sonhador que talvez, após ter se submetido a esse procedimento de desnudamento radical, talvez esse Sem Nome o ame. Para uma leitura mais didática do poema, vale a pena segmentá-lo em unidades de sentido, priorizando os seus aspectos semânticos:

\begin{tabular}{|c|c|}
\hline Honra-me & Com teus nadas \\
\hline Traduz meu passo & De maneira que eu nunca me perceba \\
\hline \multirow{2}{*}{ Confunde estas linhas que te escrevo } & Como se um brejeiro escoliasta/Resolvesse/ \\
\hline & Brincar a morte de seu próprio texto \\
\hline \multirow[t]{4}{*}{ Dá-me } & pobreza e fealdade e medo \\
\hline & e desterro de todas as respostas/que dariam luz/a \\
\hline & meu entendimento cego. \\
\hline & tristes joelhos./ Para que eu possa fincá-los num \\
\hline \multirow[t]{2}{*}{ Dá-me } & mínimo de terra/ $\mathrm{E}$ ali permanecer o teu mais \\
\hline & esquecido prisioneiro. \\
\hline \multirow[t]{3}{*}{ Dá-me } & Mudez. E andar desordenado. \\
\hline & Nenhum cão./ Tu sabes que amo os animais/Por \\
\hline & isso me sentiria aliviado \\
\hline E de ti, Sem Nome & Não desejo alívio. Apenas estreitez e fardo. \\
\hline Talvez assim te encantes & de tão farta nudez \\
\hline Talvez assim me ames: & desnudo até o osso. / Igual a um morto. \\
\hline
\end{tabular}

O cantar de amor na lírica hilstiana torna-se um método de divinização do ser a quem se dirige esse canto, e tem sua contraparte em um conjunto de ações com o objetivo de que o sujeito amoroso esteja à altura do Amado, e por isto ele sofre a imposição de duas forças contrárias 
e complementares: a ascese, que deixa no corpo do sujeito lírico desnudo até o osso - as marcas de um exercício de desprendimento, mas não apenas no sujeito amante, também o ser Amado e divinizado passará por um processo de transcendência que por fim culminará no apofatismo; em contrapartida, o excesso metaforizado no vermelho intenso das amoras, no carmim e no rubro, cores que, como vimos, o louco de Via Espessa aconselha a Samsara - que é o eu lírico poeta, sujeito amante dos poemas hilstianos - a viver. Exceder a própria medida é próprio dos textos hilstianos, principalmente quando se pensa na anarquia entre os gêneros que ela promove em sua prosa. Mas, falando apenas de sua lírica, o excesso está também nesse investimento absoluto na paixão amorosa como fonte de conhecimento de e para Deus, considerando-se que a partir de JMNP há uma clara tendência de divinização no objeto de afeto dos poemas amorosos, de tal modo que parece correto valorar esse procedimento de transcentalização significativo para a totalidade de sua lírica, não apenas aquela sensivelmente mística.

No conjunto de poema Via vazia (1989, poema V), o sujeito lírico explicita, em linguagem poética, o que se tentou até agora explicar:

Dá-me a via do excesso. O estupor.

Amputado de gestos, dá-me a eloquência do Nada

Os ossos cintilando

$\mathrm{Na}$ orvalhada friez do teu deserto.

\section{\&\&\&}

Para finalizar, passemos aos dois últimos poemas que estão no último livro que Hilda publicou, o CDNSP, e nessa singular posição de derradeiros parecem justificar e sustentar toda a poesia publicada até então.

\section{Poema IX}

Ilhargas, osso, algumas vezes é tudo que se tem.

Pensas de carne a ilha, e majestoso o osso.

E pensas maravilha quando pensas anca 
Quando pensas virilha pensas gozo.

Mas tudo mais falece quando pensas tardança

E te despedes.

E quando pensas breve

Teu balbucio trêmulo, teu texto-desengano

Que te espia, e espia o pouco tempo te rondando a ilha.

E quando pensas VIDA QUE ESMORECE. E retomas

Luta, ascese, e as mós vão triturando

Tua esmaltada garganta.... Mas assim mesmo

Canta! Ainda que se desfaçam ilhargas, trilhas....

Canta o começo e o fim. Como se fosse verdade

A esperança.

\section{Poema X}

Como se fosse verdade encantações, poemas

Como se Aquele ouvisse arrebatado

Teus cantares de louca, as cantigas da pena.

Como se a cada noite de ti se despedisse

Com colibris na boa.

E candeias e frutos, como se fosses amante

E estivesse de luto, e Ele, o Pai

Te fizesse porisso adormecer....

(Como se se apiedasse porque humana

És apenas poeira,

E Ele o grande Tecelão da tua morte: a teia.

O poema IX se inicia com a declaração pessimista de que a carne perecível é, não raras vezes, tudo que se tem, ainda que algumas ilusões nos distraiam da VIDA QUE ESMORECE - e a grafia em caixa alta escolhida pela autora não é gratuita, soa como um grito impotente que atravessa a esmaltada garganta desse a quem é dado o imperativo: Canta! É como se o eu lírico, poeta, falasse a si mesmo, ou a outro poeta de igual calibre, a quem luta e ascese fazem o mesmo apelo. É esse ser poeta, dono de adornada garganta, que recebe duas vezes a mesma ordem: na primeira o verbo tem como complemento uma oração concessiva que intensifica a 
urgência desse canto, que deve acontecer ainda que o corpo ("ilhargas", v. 13) e os caminhos demarcados ("trilhas", v. 13) se desintegrem; na segunda acompanha o verbo imperativo uma especificação desse canto, que deve abranger vida e morte ("o começo e o fim", v. 14), canto que é comparado - a conjunção "como se" tem valor de comparação - àquele que nasce da convicção da esperança.

E no próximo poema sucedem-se cinco versos com a mesma estrutura sintático-semântica, segundo o esquema abaixo:

Como se

- fossem verdade encantações, poemas....

- Aquele ouvisse arrebatado/teus cantares de louca

- a cada noite de ti se despedisse/ com colibris na boca

- fosses amante/ e estivesse de luto, e Ele, o Pai/ Te fizesse porisso adormecer

- se apiedasse porque humana/ és apenas poeira

Considerando-se os dois poemas, que estão inegavelmente associados, serão seis estruturas sintáticas que se prestam a caracterizar a origem e espessura desse canto. $\mathrm{O}$ segmento do poema IX e o primeiro do poema X usam o mesmo vocábulo como critério de comparação: verdade. Como se de fato fosse verdade a esperança, e também encantações, poemas, Canta! As outras quatro ocorrências dessa estrutura linguística falam da existência e das ações de um ser que é nominado Aquele, Ele, o Pai, Tecelão, respectivamente, parecendo se tratar da mesma pessoa, se de pessoa se trata porque as maiúsculas, e o uso do substantivo "pai", também em maiúscula, aponta para a divindade desse personagem. Em sendo uma estrutura regida por uma conjunção comparativa ("como") que vem acompanhada de outra condicional ("se") a locução, apesar de seu valor preponderante de comparação, ganha conotação de dúvida, possibilidade, hipótese, o que leva à provável leitura de que tais assertivas - complementares a cada uma das estruturas iniciadas pelo "como se" podem não passar de aspirações do sujeito lírico. 
Aspirações como a de Ruiska, personagem da primeira narrativa de Hilda, Fluxo-Floema, que é um escritor fechado em seu escritório em diálogo com suas personagens, em especial um anão. Quero retornar a um trecho desse texto, que serve de epígrafe desse ensaio:

Ruiska, o que é que procuras? Deus? E tu pensas que ele se fará aqui, na tua página? No teu caminhar de louco? No silêncio de tua vaidade? Sim, no teu caminhar de louco, em ti todo fragmentado, abjeto. Ele se fará na vontade que tens de quebrar o equilíbrio, de te estilhaçares [...] (HILST, 2018, p. 52)

Alimenta-os, ao eu lírico do poema lido e ao personagem Ruiska, bem como a diversos outros personagens hilstianos, a esperança de que a palavra seja não apenas esse corriqueiro instrumento de comunicação, que ela seja também, e além, canto eloquente e apelo a um Alguém grande Tecelão da teia da vida, como as parcas, dirá o poema acima - que, quer nomeado como Deus, quer apenas indicada sua transcendência em apóstrofes negativas, é muito Amado e Desejado. No trecho lido dizse que "Ele se fará na vontade que tens de quebrar o equilíbrio, de te estilhaçares”, em outras palavras, tornar-se-á Presença quando o desejo de autopreservação e conservação for superado por um outro mais intenso de estilhaçar a própria medida, configurando a ação soberana, conforme o pensamento de Bataille - nome tão lido e querido pela própria Hilda Hilst -, aquela na qual o ser se põe em questão e desafia os interditos que protegem a vida humana de tudo que é excessivo.

\section{THIS MAGNETIZED SONG}

\section{Abstract}

The article seeks to identify in Hilda Hilst's poetry, from the 1970s, a movement of sublimation of loving singing, sometimes found in the field of immanence and sometimes deified by negative interpolations, such as Cara Negra, Aquele Outro, Nothing, Sombrio unnamed. , Big Face, etc. He argues that there is a method of transcendence in Hilda Hilst's love poetry, both for the lyrical subject, who suffers 
from love, and for the beloved who causes this suffering. This chant is organized from two pendular movements: asceticism, understood as a movement of detachment; and excess, understood as an absolute investment in loving passion and a privileged method of knowing God.

KEYworDs: Hilda Hilst; lyric; asceticism; excess; representations of God.

\section{ESTA CANCIÓN MAGNETIZADA}

\section{RESUMEN}

El artículo busca identificar en la lírica de Hilda Hilst después de la década de 1970 un movimiento vertical de el canto del amor, que ahora está en el campo de la inmanencia, y que a veces se deifica a través de interpolaciones negativas como Cara oscura, Ese Otro, Nada, Sin Nombre, Oscuro, Gran Cara. Argumenta que hay un canto de amor como mé-todo de trascendencia, tanto del sujeto lírico, que sufre del amor, como del amado que causa este sufrimiento. Este canto se organiza a partir de dos movimientos pendulares que sustentan la lírica de Hilst: el ascetismo, como un movimiento desinteresado, y el exceso, como una inversión absoluta en la pasión amorosa y un método privilegiado de conocer a Dios.

Palabras Clave: Hilda Hilst; lírica; ascetismo; exceso; representaciones de Dios.

\section{REFERÊNCIAS}

ABBAGNANO, Nicola. Dicionário de Filosofia. 4. ed. São Paulo: Martins fontes, 2000.

COELHO, Nelly Novaes. Da poesia. Cadernos de Literatura Brasileira, Rio de Janeiro, n. 8, out. 1999.

BATAILLE, George. A experiência interior. São Paulo: Editora Ática, 1992.

DUARTE, Edson Costa. A poesia de Hilda Hilst. Linguagens: Revista de Letras, Artes e Comunicação, Blumenau, v. 3, n. 2, p. 185-202, maio/ago. 2009.

FOUCAULT, Michel. A hermenêutica do sujeito: curso dado no Collège de France (1981-1982). São Paulo: Martins Fontes, 2010. 
HERINGER, Victor. Posfácio. In: HILST, Hilda. Da poesia. São Paulo: Companhia das Letras, 2017.

HILST, Hilda. Entrevista. Cadernos de Literatura Brasileira, Rio de Janeiro, n. 8, out. 1999.

. Da poesia. São Paulo: Companhia das Letras, 2017.

. Da prosa. $1^{\circ}$ vol. São Paulo: Companhia das Letras, 2018.

MARTINS, Luiz Renato. Do erotismo à parte maldita. In: NOVAES, Adauto (Org.). O desejo. São Paulo: Companhia das Letras, 1990.

MORAES, Eliane Robert. Da medida estilhaçada. Cadernos de Literatura Brasileira, Rio de Janeiro, n. 8, out. 1999.

OTTO, Rudolf. Lo santo, lo racional y lo irracional en la idea de Dios. Madrid: Allianza Editorial, 2005 .

PLATÃO. Diálogos. Tradução e notas de José Cavalcante de Souza, Jorge Paleikat e João Cruz Costa. São Paulo: Nova Cultural, 1991. (Coleção Os Pensadores).

PINHEIRO, Marcus. Ascese pagã. Verbete. 2020. Disponível em: <http:// theologicalatinoamericana.com/?p=1349>. Acesso em: 08 abr. 2020.

PÉCORA, Alcir. Hilda Hilst: call for papers. 2005. Disponível em: <http://www. germinaliteratura.com.br/enc_pecora_ago5.htm>. Acesso em: 29 mar. 2009.

RIBEIRO, Leo Gilson. Os versos de Hilda Hilst integrando a nossa realidade. Jornal da Tarde, São Paulo, 14 fev. 1981. p. 3-4.

SOUZA, Francisco Sales de. A mulher na poesia de Dante, Petrarca e Boccacci. Revista de Letras, v. 18, n. 2, jul./dez. 1996.

Submetido em 09 de março de 2020

Aceito em 14 de abril de 2020

Publicado em 31 de maio de 2020 